\title{
RATE OF ENTRANCE OF SODIUM INTO THE AQUEOUS HUMOUR OF THE RABBIT*
}

\author{
BY \\ D. F. COLE \\ M.R.C. Ophthalmological Research Unit, Institute of Ophthalmology, University of \\ London
}

WITH the advent of the active secretion theory of formation of the aqueous humour, increasing importance has been attached to knowledge of the rates at which the various constituents of this fluid enter the eye ( $c f$. Langham, 1958). This information is required in order to reach some understanding of aqueous humour dynamics and also to assist in elucidating the nature and action of the secreting mechanism.

The rates of flow of water and certain solutes through the anterior chamber have been estimated by studying the rates of accumulation or disappearance of Rayopake, Diodrast, or p-aminohippurate (Bárány and Kinsey, 1949), fluorescein (Goldmann, 1950; Langham and Wood, 1956), and 24Na (Kinsey and Bárány, 1949; Davson, 1955, 1956; Kinsey and Palm, 1955, 1958). Mathematical analysis of some of these findings in terms of transfer coefficients representing entrance into the anterior chamber aqueous by flow and diffusion ( $k_{f}$ and $k_{d}$, respectively) have yielded values ranging from $k_{f}=$ 0.017 - 0.018 min. $^{-1}$ (Kinsey and Palm, 1955; Friedenwald and Becker, 1956) down to $k_{f}=0.009$ min. $^{-1}$ (Davson, 1955; 1956). If the solute concentrations in plasma and aqueous humour and the volume of the anterior chamber are known, it is possible to calculate the rate of solute entering the eye at a steady state, where influx and efflux are equal. In these circumstances the rate at which solute leaves the anterior chamber for the drainage channels depends on the outflow rate and the anterior chamber concentration;

$$
\frac{d}{d t} \cdot m_{f}=c_{a} \cdot F_{o},
$$

Where $F_{o}$ is a function of the transfer coefficient and anterior chamber volume;

$$
F_{o}=k_{f} \cdot V_{a}
$$

Whereas most of the published findings are expressed as transfer coefficients rather than as absolute quantities of material entering or leaving the eye per minute, the present paper gives an account of a method for estimating the rate of sodium efflux in fluid collected from transfused eyes in which the drainage channels had been obstructed. Conditions under which this efflux is equal to the influx are considered and the findings compared with values calculated (as shown above) from the published transfer coefficients. 


\section{Methods}

The basis of the present method was to transfuse the aqueous space with a sodium-free, isotonic solution of mannitol, having blocked the drainage angle with paraffin or similar material as described by Langham (1959). A 15-gauge needle, connected to the collecting system described below, was inserted through the cornea into the anterior chamber (Fig. 1, 4) and subsequent manipulations were carried out with a pressure of not less than $30 \mathrm{~mm}$. $\mathrm{Hg}$ in the collecting system. A second needle, No 17 (Fig. 1, 1) attached to fine-bore polythene tubing was then inserted through the sclera into the posterior chamber, the free end of the polythene tubing being connected to a hypodermic syringe containing paraffin. This needle was pushed gently forwards through the pupil to enter the anterior chamber and a few drops of paraffin injected into this chamber to form a torus between the posterior surface of the cornea and the anterior surface of the iris (Fig. 1, 3 and 6). The aqueous which had been displaced during this injection was able to leave the eye through the first needle, and, owing to the pressure in the collecting system, the intra-ocular pressure was not able to decrease below $30 \mathrm{~mm}$. $\mathrm{Hg}$. When the paraffin injection had been completed, the second needle was cautiously withdrawn to occupy its final position in the posterior chamber as shown in Fig. 1 (1). The free end of the polythene tubing through which the paraffin had been injected was then connected to a motor-driven perfusion syringe containing the buffered, isotonic mannitol solution. Although paraffin (S.G. $=0.83-0.87$ ) was used in some of the earlier experiments, it was found that the silicone fluid MS/200/20 (Hopkin and Williams Ltd., London, England) was equally effective for blocking the drainage angle and, being more mobile than paraffin, more readily introduced into the eye. Once these procedures had been carried out the eye was transfused with

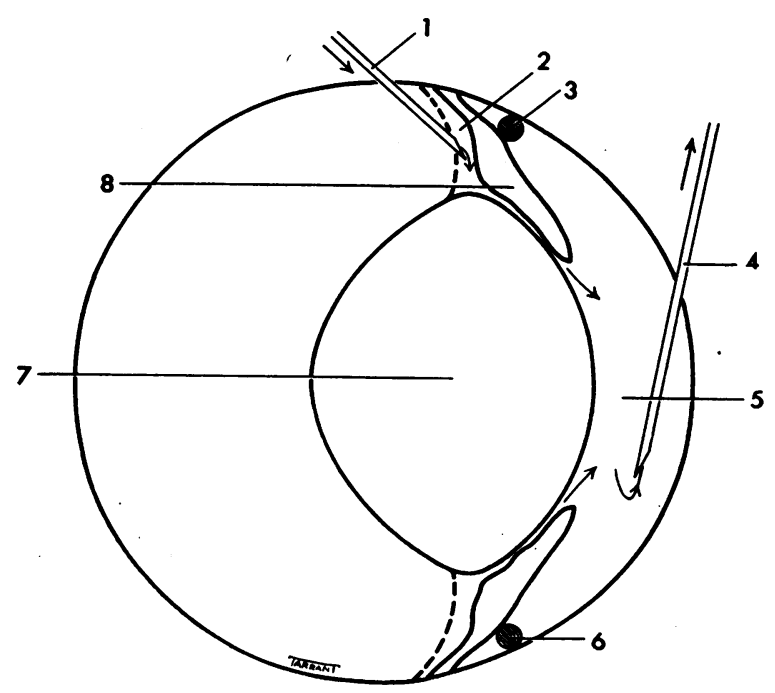

$1=$ inflow needle (connected to motordriven syringe),

$2=$ posterior chamber,

3 and $6=$ oil or silicone fluid in drainage angle,

4 = outflow needle to collecting system, $5=$ anterior chamber, $7=$ lens, $8=$ iris.

Fig. 1.-Diagrammatic transverse section of eye, showing positions of needles and oil during transfusion. 
buffered isotonic mannitol at rates which ranged between 50 and $150 \mu 1 . / \mathrm{min}$., with an effluent collection pressure between 25 and $30 \mathrm{~mm}$. $\mathrm{Hg}$.

From the outflow needle (Figs 2 and 3, A), a length of fine-bore polythene tubing led to a three-way tap (Figs 2 and 3, B and C). In the first type of collecting system (Fig. 2), the effluent from the eye was collected under a water-immiscible fluid, such as paraffin, petroleum spirit (B.P. $100-120^{\circ}$ C.), or MS $200 / 20$, as indicated in Fig. $2(\mathrm{~F}-\mathrm{G})$, the volume displaced being measured in the graduated tube, M. The effluent was collected at $\mathrm{E}$, and, from time to time, expelled through the three-way stop-cock, D, by means of the syringe, $\mathrm{K}$. The height of $\mathrm{M}$ could be varied and the pressure against which the effluent left eye was equal to $g\left(\rho_{w}\left(h_{1}+h_{3}\right)+\rho_{f} h_{2}\right)$, where $g$ is the acceleration due to gravity, $\rho_{w}$ the density of water, $\rho_{f}$ the density of the water-immiscible fluid, and $h_{1}, h_{2}$, and $h_{3}$ the vertical heights indicated in Fig. 2.

The apparatus shown in Fig. 2 suffered from certain disadvantages, mainly because of the viscosity of the water-immiscible fluid, and most of the experiments were therefore performed with the apparatus shown in Fig. 3 (overleaf). In this second collecting system, the effluent was collected under air maintained at $30 \mathrm{~mm} . \mathrm{Hg}$ above atmospheric pressure by means of a "pressure reservoir", E, and a water reservoir, $\mathbf{L}$. The volume of effluent was measured in graduated collection tubes $\mathrm{D}$, which were connected to the "pressure reservoir", E, and the adjusting tube, $\mathrm{H}$, through the three-way stop-cock, $\mathrm{C}$, and the T-junction, G. Whilst fluid was

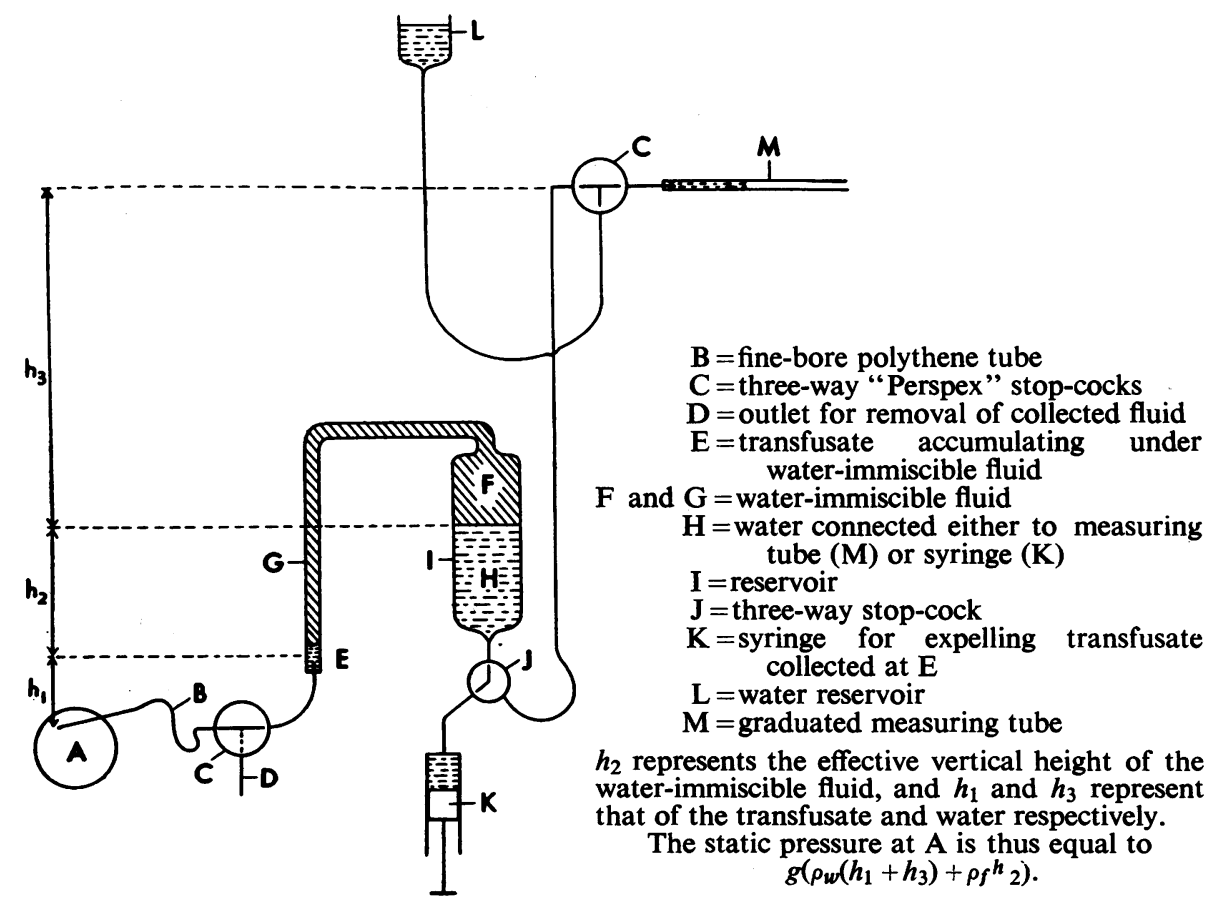

Fig. 2.-Diagram of collecting system (first type); the experimental eye and its outflow needle are represented at $\mathbf{A}$. 


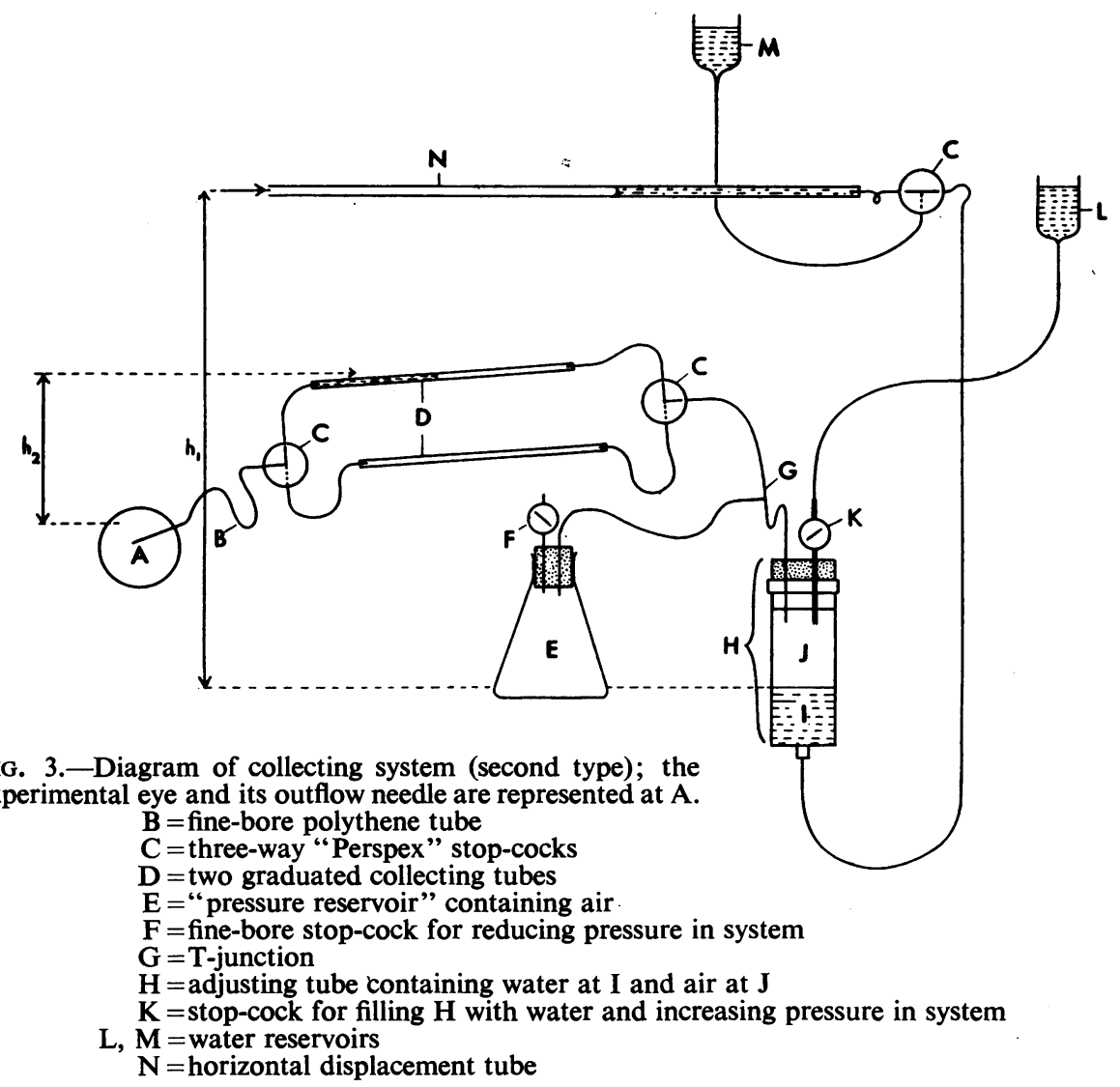

$h_{1}$ and $h_{2}$ represent the effective vertical heights of the transfusate and water respectively. The static pressure at $\mathrm{A}$ is thus equal to $g \rho_{w}\left(h_{1}+h_{2}\right)$.

being collected in $\mathrm{D}$, air was being displaced into $\mathrm{J}$, and the water from the adjusting tube, $\mathrm{H}$, was displaced from I to the horizontal tube at $\mathrm{N}$. Fine adjustment of pressure was effected by running water from the reservoir, $\mathrm{L}$, into the adjusting tube at I by opening the stop-cock, $\mathrm{K}$; pressure was reduced by allowing air to leave the system through the fine-bore stop-cock, F. Using two collecting tubes, $\mathrm{D}$, and two three-way stop-cocks, $\mathrm{C}$, uninterrupted collection could be made from the experimental eye, represented at A. The collection tubes, D, being approximately horizontal the effective pressure against which the effluent left the eye was equal to $g \rho_{w}\left(h_{1}+h_{2}\right)$, assuming similar densities for water and effluent.

Chemical Methods.-The effluent was stored in stoppered polythene tubes and sodium, potassium, and calcium estimated with a "Unicam" Flame Spectrophotometer (SP 900). Sodium was estimated in the range 0.1-0.6 $\mu$ Eq. $/ \mathrm{ml}$., potassium in the range $0.02-0.05 \mu \mathrm{Eq} . / \mathrm{ml}$., and calcium in the range $0.006-0.025$ $\mu \mathrm{M} / \mathrm{ml}$. Plasma concentrations were determined in samples of arterial blood 
obtained from the central artery of the ear half-way through each experiment. Plasma protein was estimated by the method of Phillips, van Slyke, Dole, Emerson, Hamilton, and Archibald (1945), and the value obtained was used to express electrolyte concentrations in terms of ml. plasma water (Sunderman and Boerner, 1949).

\section{Experimental Material}

The animals used in these experiments were adult rabbits of the New Zealand White strain, weighing between 2 and $3 \mathrm{~kg}$. They had been fed on Diet 18 ("Blue Cross" Animal Foodstuffs, Associated London Flour Millers, Ltd.) and allowed free access to water. All animals were anaesthetized with urethane, given intravenously as a 25 per cent. (w/v) solution in physiological saline, at a dose level of 1.75 to $2.0 \mathrm{~g} . / \mathrm{kg}$. body weight. Before the needles were inserted a few drops of 1 per cent. amethocaine (B.P.) were instilled into the eye. The animals were killed at the end of each experiment, whether or not both eyes had been used.

In some cases a flexible nylon cannula was implanted in the lingual artery on one side of the neck, using the technique described in an earlier paper (Cole, 1959). Through this cannula solutions of 2:4 dinitrophenol (DNP), Diamox (Lederle), or Mersalyl (B.P.) were infused in order to obtain a high concentration of the inhibitor in the blood supplying the experimental eye without the need for administering large doses systemically. In some animals both lingual arteries were so cannulated, the left (control) eye was transfused first whilst isotonic saline was injected into the left lingual artery. In the second half of the experiment the contralateral (experimental) eye was transfused whilst DNP was injected through the right lingual artery. In cases where this procedure had been carried out satisfactorily on both eyes of a single animal, the changes by DNP could be assessed by comparing control and experimental values for each pair of eyes; since both eyes were not always successfully transfused most of the results are based upon comparison of groups of eyes. The results obtained only from comparison of pairs of eyes are shown separately in Table III (p. 234).

Buffered Isotonic Mannitol.-This was a 5.67 per cent. (w/v) solution of mannitol containing $10 \mathrm{ml} .0 .3 \mathrm{M}$ buffer $(\mathrm{pH} 7.45)$ in each $100 \mathrm{ml}$. The buffer was a $0.3 \mathrm{M}$ solution of tris-(hydroxymethyl)-aminomethane in water brought to $\mathrm{pH} 7.45$ by addition of $3 \mathrm{~N}$ nitric acid. Usually $100 \mathrm{ml}$. tris-(hydroxymethyl)-aminomethane solution required about $8 \mathrm{ml}$. acid. The buffered isotonic mannitol was made up on the morning of the experiment.

DNP.-As described previously (Cole 1959), the DNP was infused at a rate calculated to yield a concentration of $0 \cdot 2-0 \cdot 3 \mathrm{mM} / \mathrm{L}$. in the blood reaching the eye, assuming the carotid blood flow to be $3 \mathrm{ml} . / \mathrm{min}$. (Winterstein, 1935). In these experiments a $40 \mathrm{mM}$ solution of DNP in. isotonic saline was infused at 0.0006-0.0009 $\mathrm{mM} / \mathrm{min}$.

Diamox.-The sodium salt of Diamox (2-acetylamino-1, 3, 4-thia-diazole-5-sulphonamide) was dissolved in isotonic saline brought to $\mathrm{pH} 7 \cdot 4$ and injected at $0.002 \mathrm{mM} / \mathrm{min}$.

Mersalyl.-Mersalyl acid anhydride (salicyl-( $\gamma$-hydroxymercuri- $\beta$-methoxypropyl)amide-O-acetic anhydride; Burroughs Wellcome, London), was dissolved in $\mathbf{0 . 3} \mathrm{N}$ sodium hydroxide, brought to $\mathrm{pH} 7 \cdot 4$, diluted with isotonic saline, and injected at $0.003 \mathrm{mM} / \mathrm{min}$. 
In all cases in which inhibitors were given, the transfusion and administration of inhibitor were begun simultaneously, and both were continued for at least 120 minutes.

\section{Results}

The symbols used in describing and discussing the results are essentially those of Duke-Elder and Maurice (1957), with the following additions:

$V_{e}$ represents the volume of effluent in $\mathrm{ml}$.

$F_{e}$ represents the rate of flow of effluent in $\mathrm{ml} . / \mathrm{min}$.

$F_{o}$ represents the outflow rate of a normal untouched eye in $\mathrm{ml} . / \mathrm{min}$.

$c_{e}$ represents the concentration in the effluent fluid of some previously specified solute and is in $\mu \mathrm{Eq}$. or $\mu \mathrm{M} / \mathrm{ml}$.

$v_{a e}$ represents the net volume moved from aqueous humour to effluent in $\mathrm{ml}$.

$t$, or $t_{n}$, as subscripts, represent time-intervals in minutes from the start of the experiment.

$n$, as a subscript, designates the $n^{\text {th }}$ collection period.

The effluent concentration and flow rate are related to the rate at which sodium ion leaves the aqueous by the expression:

$$
\left[\frac{d}{d t} \cdot m_{a e}\right]_{t}=\left[c_{e} \cdot F_{e}\right]_{t} \cdot \cdot \quad . \quad . \quad . \quad . \quad .
$$

and it is obvious that, until a steady-state is reached, $c_{e}$ will change continuously during the course of any collection period, say from $t_{(n-1)}$ to $t_{n}$ (in the case of the $n^{\text {th }}$ period). At the end of the $n^{\text {th }}$ collection period, the total sodium efflux for that period will be $\left[c_{e} \cdot V_{e}\right]_{n}$ and the total amount of sodium which has left the aqueous since the start of the experiment, that is to say from $t=0$ to $t=t_{n}$, will be given by $\sum_{o}^{n}\left(c_{e} \cdot V_{e}\right)$. Assuming this to be equal to $\int_{t=0}^{t=t_{n}}\left(c_{e} F_{e}\right) \cdot d t ;\left[\frac{d}{d t} m_{a e}\right]_{t}$ may be calculated for various values of $t\left(0<t<t_{n}\right)$ by numerical differentiation of $\sum_{o}^{n}\left(c_{e} \cdot V_{e}\right)$ with respect to time. The volume of effluent and its sodium concentration for each collection period being known, $\sum_{o}^{n}\left(c_{e} \cdot V_{e}\right)$ could be calculated for periods from 1 to $n$. These values were plotted against time and the resulting series of points joined by a smooth curve; from this curve, values for $\sum\left(c_{e} \cdot V_{e}\right)$ were read off for successive 10-minute time-intervals, to give values for $\int_{t=0}^{t=10}\left(c_{e} \cdot F_{e}\right) \cdot \mathrm{dt}$, 
$t=20$

$\int_{t=0}^{t=20}\left(c_{e} \cdot F_{e}\right) \cdot d t$, etc. The differential at each time-interval was then calculated by means of Newton's approximation:

$$
\frac{d}{d t} \cdot m=\frac{1}{\lambda}\left(\triangle_{1}-\frac{\triangle_{2}}{2}+\frac{\triangle_{3}}{3}\right), \quad \text {. . . . . }
$$

(where $\triangle_{1}, \triangle_{2}$, and $\triangle_{3}$ are the first, second and third differences respectively, and $\lambda$ is the length of each time-interval, i.e. 10 minutes) (cf. Lipka, 1918), to give values of $\left[\frac{d}{d t} \cdot m_{a e}\right]_{t}$ for the times, $t=10, t=20, t=30, \ldots$ etc. A similar procedure was used to calculate the efflux rates of potassium and calcium, and the outflow rates of water:

$$
\frac{d}{d t} \cdot V_{a e}=F_{e} \text {. }
$$

The solute concentrations at any instant could be calculated from the expression:

$$
\left(c_{e}\right)_{t}=\left[\frac{d}{d t} \cdot m_{a e}\right]_{t} \div\left[\frac{d}{d t} \cdot V_{a e}\right]_{t} \cdot . \quad . \quad .
$$

Since the early stages of the experiment consisted mainly in washing out the sodium and other solutes already present in the aqueous it is reasonable to anticipate that were this the only factor involved the rate of sodium efflux would decrease exponentially to zero. However, if sodium were continually entering the aqueous from the plasma a steady-state would be reached with $\frac{d}{d t} \cdot c_{e} \rightarrow 0$ and, where $\frac{d}{d t} \cdot m_{a e}$ did not decrease to zero but equalled the rate at which sodium was entering the aqueous from the plasma, with $\frac{d}{d t} \cdot m_{p a}$.

Thus, the values for $\frac{d}{d t} \cdot m_{a e}$ observed after the preparation had reached a steady-state, or alternatively, the value to which $\frac{d}{d t} \cdot m_{a e}$ approximated as the experiment proceeded, should give an estimate of the entrance rate of the solute in question. In fact, it was found that the results fitted reasonably well to a double exponential equation of the form:

$$
\begin{aligned}
\frac{d}{d t} \cdot m_{a e_{t}} & =\mathrm{A} \cdot e^{-\alpha \cdot t}+\mathrm{B} \cdot e^{-\beta \cdot t}+\mathrm{C} \\
& \rightarrow \frac{d}{d t} \cdot m_{p a}\left(\text { where } \frac{d}{d t} \cdot c_{e} \rightarrow 0\right) \quad . \quad .
\end{aligned}
$$


If the rate of entrance of one of the solutes were either completely or partially arrested, a decrease of the values for $\frac{d}{d t} \cdot m_{a e}$ (steady state) would be expected. Several metabolic inhibitors known to reduce ion transport in other tissues were used, the most frequently employed being DNP.

Results from eyes which appeared to be abnormal or from which leakages were suspected were discarded. The results given in Tables I and II are based on results from not less than twenty eyes, and those in Table II (overleaf) from not less than ten. Except in Table IV (overleaf), the figures represent means and standard errors of means.

The results fall into three groups:

(a) Results from eyes in which no inhibitor had been given (controls);

(b) Results from eyes in which either DNP or Diamox or Mersalyl had been given as described above,

TABLE I

EFFLUX OF WATER, SODIUM, POTASSIUM, AND CALCIUM (IN $\mu$ l., $\mu$ Eq., $\mu \mu$ Eq., THE COMMENCEMENT

The values represent the Mean \pm its

\begin{tabular}{|c|c|c|c|c|c|}
\hline \multicolumn{2}{|c|}{ Time from Start of Transfusion (min.) } & 10 & 20 & 30 & 40 \\
\hline \multirow{3}{*}{$\begin{array}{l}\text { Rate of Outflow } \\
F_{e}(\mu 1 . \text { min. })\end{array}$} & Controls & $\begin{array}{r}73.0 \\
\pm 10.5\end{array}$ & $\begin{array}{r}74 \cdot 7 \\
\pm 8 \cdot 3\end{array}$ & $\begin{array}{r}49 \cdot 6 \\
\pm 7 \cdot 9\end{array}$ & $\begin{array}{r}50 \cdot 5 \\
\pm 4 \cdot 7 \\
\end{array}$ \\
\hline & + Inhibitor (pooled) & $\begin{array}{r}75 \cdot 0 \\
\pm 7 \cdot 2\end{array}$ & $\begin{array}{r}75 \cdot 0 \\
\pm 7 \cdot 1 \\
\end{array}$ & $\begin{array}{r}52 \cdot 1 \\
\pm 7 \cdot 0\end{array}$ & $\begin{array}{r}49 \cdot 7 \\
\pm 3 \cdot 9 \\
\end{array}$ \\
\hline & + DNP only & $\begin{array}{r}79 \cdot 0 \\
\pm 8 \cdot 2\end{array}$ & $\begin{array}{r}80 \cdot 6 \\
\pm 3 \cdot 1\end{array}$ & $\begin{array}{r}59 \cdot 9 \\
\pm 7 \cdot 1\end{array}$ & $\begin{array}{r}54 \cdot 2 \\
\pm 4 \cdot 2\end{array}$ \\
\hline \multirow{3}{*}{$\begin{array}{c}\text { Sodium Efflux } \\
\frac{d}{d t} \cdot m_{a e}(\mu \mathrm{Eq} . / \mathrm{min} .)\end{array}$} & Controls & $\begin{array}{r}1.96 \\
\pm 0.54\end{array}$ & $\begin{array}{r}1.35 \\
\pm 0.46\end{array}$ & $\begin{array}{r}1 \cdot 22 \\
\pm 0 \cdot 36\end{array}$ & $\begin{array}{l}0.969 \\
+0.17\end{array}$ \\
\hline & + Inhibitors (pooled) & $\begin{array}{r}1 \cdot 66 \\
\pm 0 \cdot 34\end{array}$ & $\begin{array}{l}0.916 \\
\pm 0.54\end{array}$ & $\begin{array}{l}\mathbf{0 . 5 9 4} \\
\pm \mathbf{0} 23\end{array}$ & $\begin{array}{l}\mathbf{0 . 5 0 0} \\
\pm \mathbf{0} \cdot 15\end{array}$ \\
\hline & +DNP only & $\begin{array}{r}2.65 \\
\pm 0.91 \\
\end{array}$ & $\begin{array}{r}1.05 \\
\pm 0.37 \\
\end{array}$ & $\begin{array}{ll} & 0.550 \\
\pm & 0.22 \\
\end{array}$ & $\begin{array}{ll} & 0.400^{*} \\
\pm & 0.11\end{array}$ \\
\hline \multirow{2}{*}{$\begin{array}{l}\text { Potassium Efflux } \\
\frac{d}{d t} \cdot m_{a e}(\mu \mu \mathrm{Eq} . / \mathrm{min} .)\end{array}$} & Controls $\quad .$. & $\begin{array}{r}197 \cdot 3 \\
\pm 12 \cdot 8\end{array}$ & $\begin{array}{r}88.0 \\
\pm 5.9\end{array}$ & $\begin{array}{r}80 \cdot 7 \\
\pm 16.5\end{array}$ & $\begin{array}{r}31 \cdot 6 \\
\pm 1 \cdot 3\end{array}$ \\
\hline & +DNP only & $\begin{array}{l}132 \cdot 2 * \\
\pm 14.9\end{array}$ & $\begin{array}{l}56.9 * * \\
\pm 6.5\end{array}$ & $\begin{array}{l}32 \cdot 9 * \\
\pm 7 \cdot 4\end{array}$ & $\begin{array}{r}30 \cdot 0 \\
\pm 6.8\end{array}$ \\
\hline \multirow{2}{*}{$\begin{array}{c}\text { Calcium Efflux } \\
\frac{d}{d t} \cdot m_{a c}(\mu \mu \mathrm{M} / \min .)\end{array}$} & Controls $\quad$. & & & & \\
\hline & +DNP only & & & & \\
\hline
\end{tabular}

Values for treated animals which differ significantly from the controls are shown by 
(c) Results from eyes in which DNP had been given.

Thus $(c)$ is a sub-group of $(b)$; all the results in $(c)$ are also contained in (b), which also comprises results not contained in $(c)$, namely the cases in which Diamox or Mersalyl was used instead of DNP.

Table I shows efflux rates at 10-minute intervals from $t=10$ to $t=120$; Table II (overleaf) shows the mean effluent concentrations over the period $t=80$ to $t=120$. Table III (overleaf) is based upon experiments in which both eyes from animals were used, the one serving as a control whilst the other was subjected to DNP poisoning. The values at each time interval represent the means of the differences for each pair between the efflux from the control eye and that from the experimental eye. Table IV (overleaf) shows the empirical coefficients for Equation 4 for each of the three groups of animals.

and $\mu \mu \mathrm{M}$ /min. RESPECTIVELY) AT SUCCESSIVE 10-MINUTE INTERVALS AFTER OF TRANSFUSION.

Standard Error for each time-interval.

\begin{tabular}{|c|c|c|c|c|c|c|c|}
\hline 50 & 60 & 70 & 80 & 90 & 100 & 110 & 120 \\
\hline $\begin{array}{r}56 \cdot 1 \\
\pm 4 \cdot 6\end{array}$ & $\begin{array}{r}52.4 \\
\pm 6.6\end{array}$ & $\begin{array}{r}53 \cdot 1 \\
\pm 4 \cdot 5\end{array}$ & $\begin{array}{r}52 \cdot 2 \\
\pm 5 \cdot 8\end{array}$ & $\begin{array}{r}50.8 \\
\pm 3.6\end{array}$ & $\begin{array}{r}53 \cdot 3 \\
\pm 4 \cdot 1\end{array}$ & $\begin{array}{r}53.0 \\
\pm 4.5\end{array}$ & $\begin{array}{r}52.7 \\
\pm 3.0\end{array}$ \\
\hline $\begin{array}{r}53 \cdot 2 \\
\pm 4 \cdot 9\end{array}$ & $\begin{array}{r}51 \cdot 7 \\
\pm 3 \cdot 2\end{array}$ & $\begin{array}{r}51 \cdot 4 \\
\pm 2 \cdot 1\end{array}$ & $\begin{array}{r}49 \cdot 0 \\
\pm 5.5\end{array}$ & $\begin{array}{r}48 \cdot 2 \\
\pm 3.9\end{array}$ & $\begin{array}{r}49 \cdot 6 \\
\pm 4 \cdot 2\end{array}$ & $\begin{array}{r}51 \cdot 2 \\
\pm 5 \cdot 1\end{array}$ & $\begin{array}{r}51 \cdot 3 \\
\pm 2.8\end{array}$ \\
\hline $\begin{array}{r}55 \cdot 4 \\
\pm 4.9\end{array}$ & $\begin{array}{r}52.8 \\
\pm 3.4\end{array}$ & $\begin{array}{r}53 \cdot 8 \\
\pm 4 \cdot 2\end{array}$ & $\begin{array}{r}62 \cdot 0 \\
\pm 3 \cdot 1\end{array}$ & $\begin{array}{r}56 \cdot 7 \\
\pm 4 \cdot 3\end{array}$ & $\begin{array}{r}51 \cdot 2 \\
\pm 4 \cdot 2\end{array}$ & $\begin{array}{r}50 \cdot 0 \\
\pm 3 \cdot 1\end{array}$ & $\begin{array}{r}50.5 \\
\pm 3.8\end{array}$ \\
\hline $\begin{array}{l}0.877 \\
\pm 0.12\end{array}$ & $\begin{array}{r}0.799 \\
\pm 0.093\end{array}$ & $\begin{array}{r}0.735 \\
\pm 0.073\end{array}$ & $\begin{array}{r}0.675 \\
\pm 0.064\end{array}$ & $\begin{array}{r}0.625 \\
\pm 0.065\end{array}$ & $\begin{array}{r}0.608 \\
\pm 0.087\end{array}$ & $\begin{array}{r}0.671 \\
\pm 0.082\end{array}$ & $\begin{array}{r}0.658 \\
\pm 0.091\end{array}$ \\
\hline $\begin{array}{l}0.438^{*} \\
\pm 0.10\end{array}$ & $\begin{array}{l}0.453^{*} \\
\pm 0.065\end{array}$ & $\begin{array}{c}0.392^{*} \\
\pm 0.095\end{array}$ & $\begin{array}{ll} & 0.353^{*} \\
\pm & 0.98\end{array}$ & $\begin{aligned} & 0.294^{* *} \\
\pm & 0.057\end{aligned}$ & $\begin{aligned} & 0.274^{* *} \\
\pm & 0.041\end{aligned}$ & $\begin{array}{l}0.264^{* *} \\
\pm 0.047^{2}\end{array}$ & $\begin{array}{l}0.254^{* *} \\
\pm 0.050\end{array}$ \\
\hline $\begin{array}{l}0.400^{*} \\
\pm 0.091\end{array}$ & $\begin{array}{c}0.482^{*} \\
\pm 0.091\end{array}$ & $\begin{aligned} & 0.447^{* *} \\
\pm & 0.048\end{aligned}$ & $\begin{array}{c}0.394^{*} \\
\pm 0.072\end{array}$ & $\begin{array}{r}0.329 * * \\
\pm 0.039\end{array}$ & $\begin{array}{l}0.306^{*} \\
\pm 0.040\end{array}$ & $\begin{aligned} & 0.299 * * \\
\pm & 0.040\end{aligned}$ & $\begin{array}{l}0.289^{* *} \\
\pm 0.040\end{array}$ \\
\hline $\begin{array}{r}37.6 \\
\pm 9.0\end{array}$ & $\begin{array}{r}27 \cdot 6 \\
\pm 5 \cdot 1\end{array}$ & $\begin{array}{r}32 \cdot 5 \\
\pm 5 \cdot 9\end{array}$ & $\begin{array}{r}29 \cdot 8 \\
\pm 5 \cdot 8\end{array}$ & $\begin{array}{r}31.9 \\
\pm 6.1\end{array}$ & $\begin{array}{r}32.9 \\
+7.5\end{array}$ & $\begin{array}{r}30.0 \\
\pm 7.5\end{array}$ & $\begin{array}{r}27 \cdot 8 \\
\pm 7 \cdot 2\end{array}$ \\
\hline $\begin{array}{r}29 \cdot 3 \\
\pm 12 \cdot 7\end{array}$ & $\begin{array}{l}27 \cdot 7 \\
\pm 8 \cdot 5\end{array}$ & $\begin{array}{r}32 \cdot 3 \\
\pm 12 \cdot 5\end{array}$ & $\begin{array}{l}27 \cdot 6 \\
\pm 7 \cdot 3\end{array}$ & $\begin{array}{r}31 \cdot 4 \\
\pm 3.9\end{array}$ & $\begin{array}{r}28 \cdot 3 \\
\pm 7 \cdot 1\end{array}$ & $\begin{array}{r}29 \cdot 5 \\
\pm 6.0\end{array}$ & $\begin{array}{l}31.6 \\
\pm 3.9\end{array}$ \\
\hline $\begin{array}{c}26 \cdot 65 \\
\pm 4 \cdot 3\end{array}$ & $\begin{array}{l}\quad 8 \cdot 16 \\
\pm 3 \cdot 2\end{array}$ & $\begin{aligned} & 8 \cdot 56 \\
\pm & 2 \cdot 5\end{aligned}$ & $\begin{array}{l}10 \cdot 26 \\
\pm 2 \cdot 7\end{array}$ & $\begin{aligned} & 7 \cdot 98 \\
\pm & 3 \cdot 1\end{aligned}$ & $\begin{array}{r}10.9 \\
\pm 1.5\end{array}$ & $\begin{array}{r}10 \cdot 1 \\
\pm 1 \cdot 1\end{array}$ & $\begin{array}{r}10 \cdot 5 \\
\pm 1.0\end{array}$ \\
\hline $\begin{array}{l}19 \cdot 57 \\
\pm 2 \cdot 1\end{array}$ & $\begin{array}{r}11.7 \\
\pm 1.7\end{array}$ & $\begin{array}{r}10 \cdot 1 \\
\pm 2 \cdot 3\end{array}$ & $\begin{aligned} & 8 \cdot 38 \\
\pm & 2 \cdot 1\end{aligned}$ & $\begin{aligned} & 6 \cdot 98 \\
\pm & 1 \cdot 8\end{aligned}$ & $\begin{aligned} & 4.98^{*} \\
\pm & 1.7\end{aligned}$ & $\begin{aligned} & 6 \cdot 83 \\
\pm & 2 \cdot 1\end{aligned}$ & 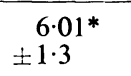 \\
\hline
\end{tabular}

asterisks; thus the range $0.05>P>0.02$ is indicated by $*$ and the range $0.02>P$ by $* *$. 
TABLE II

MEAN VALUES AND STANDARD ERRORS OF MEANS FOR CONCENTRATIONS IN TRANSFUSATE BETWEEN 80 AND 120 MIN. AFTER THE START OF THE EXPERIMENTS AND FOR TERMINAL CONCENTRATIONS IN ARTERIAL PLASMA

\begin{tabular}{|c|c|c|c|c|c|c|c|}
\hline Concentration & \multicolumn{5}{|c|}{ Subjects } & Transfusate & Plasma \\
\hline \multirow{3}{*}{$\underset{(\mu \mathrm{Eq} . / \mathrm{ml} .)}{\text { Sodium }}$} & Controls & . & . & . & . & $12 \cdot 37 \pm 0.9$ & \\
\hline & +Inhibitc & $(\mathrm{p}$ & d) & . . & .. & $5 \cdot 79 \pm 0 \cdot 7^{* *}$ & \multirow{2}{*}{$\begin{array}{r}151 \cdot 0 \\
\pm 1 \cdot 3\end{array}$} \\
\hline & $+\mathrm{DNP}$ & . & . & .. & . & $5 \cdot 96 \pm 0 \cdot 8^{* *}$ & \\
\hline \multirow{2}{*}{$\begin{array}{l}\text { Potassium } \\
(\mu \mathrm{Eq} . / \mathrm{ml} .)\end{array}$} & Controls & . & . & . & . & $0.581 \pm 0.02$ & \multirow{2}{*}{$\begin{array}{r}4.97 \\
\pm 0 \cdot 21\end{array}$} \\
\hline & $+\mathrm{DNP}$ & . & . & . & . & $0.581 \pm 0.02$ & \\
\hline \multirow{2}{*}{$\begin{array}{l}\text { Calcium } \\
(\mu \mathrm{M} / \mathrm{ml} .)\end{array}$} & Controls & . & . & . & . & $0.188 \pm 0.02$ & \multirow{2}{*}{$\begin{array}{r}1 \cdot 50 \\
\pm 0 \cdot 10\end{array}$} \\
\hline & +DNP & . & . & . & . & $0 \cdot 118 \pm 0.02^{* *}$ & \\
\hline
\end{tabular}

Values which differ significantly from the controls are shown by asterisks; thus the range $0.02>P$ is indicated by $* *$.

TABLE III

DIFFERENCES OF EFFLUX RATES BETWEEN THE TWO EYES OF THOSE ANIMALS IN WHICH THE ONE EYE HAD SERVED AS A CONTROL AND THE OTHER HAD BEEN SUBJECTED TO DNP POISONING

Values represent means of differences (control-experimental) and their standard errors at 10-minute intervals from 50 to $120 \mathrm{~min}$. after the start of the transfusion

\begin{tabular}{|c|c|c|c|c|c|c|c|c|}
\hline $\begin{array}{l}\text { Time from Start of } \\
\text { Transfusion (min.) }\end{array}$ & 50 & 60 & 70 & 80 & 90 & 100 & 110 & 120 \\
\hline $\begin{array}{l}\text { Sodium Efflux } \\
(\mu \mathrm{Eq} . / \text { min.) (con- } \\
\text { trol-experimental) }\end{array}$ & $\begin{array}{l}+0.395 * * \\
\pm 0.11\end{array}$ & $\begin{array}{l}+0.290^{* *} \\
\pm 0.11\end{array}$ & $\begin{array}{l}+0 \cdot 285^{* *} \\
\pm 0 \cdot 10\end{array}$ & $\begin{array}{l}+0.283^{* *} \\
\pm 0.07\end{array}$ & $\begin{array}{l}+0.361 * * \\
\pm 0.09\end{array}$ & $\begin{array}{l}+0.394 * * \\
\pm 0.11\end{array}$ & $\begin{array}{l}+0.387^{* *} \\
\pm 0.12\end{array}$ & $\begin{array}{l}+0.380 * * \\
\pm 0.04\end{array}$ \\
\hline $\begin{array}{l}\text { Potassium Efflux } \\
\text { ( } \mu \mu \mathrm{Eq} \text {-/min.) (con- } \\
\text { trol-experimental) }\end{array}$ & $\begin{array}{l}-26 \cdot 9 * * \\
\pm 3 \cdot 2\end{array}$ & $\begin{array}{l}-6 \cdot 3 \\
\pm 2 \cdot 7\end{array}$ & $\begin{array}{l}-7 \cdot 4^{*} \\
\pm 2 \cdot 9\end{array}$ & $\begin{array}{l}-7 \cdot 6 \\
\pm 3.8\end{array}$ & $\begin{array}{l}-3.4 \\
\pm 3.4\end{array}$ & $\begin{array}{l}-11 \cdot 3 * * \\
\pm 3 \cdot 4\end{array}$ & $\begin{array}{l}-8 \cdot 5^{* *} \\
\pm 2 \cdot 4\end{array}$ & $\begin{array}{l}-5 \cdot 2^{* *} \\
\pm 1,9\end{array}$ \\
\hline $\begin{array}{l}\text { Calcium Efflux } \\
(\mu \mu \mathrm{M} / \text { min.)(con- } \\
\text { trol-experimental) }\end{array}$ & $\begin{array}{l}-5 \cdot 8^{*} \\
\pm 2 \cdot 1\end{array}$ & $\begin{array}{l}-3.6 \\
\pm 2.0\end{array}$ & $\begin{array}{l}-1 \cdot 6 \\
\pm 1.7\end{array}$ & $\begin{array}{l}+1 \cdot 3 \\
\pm 1 \cdot 8\end{array}$ & $\begin{array}{l}+4 \cdot 5^{*} \\
\pm 1.8\end{array}$ & $\begin{array}{l}+3.5 \\
\pm 1.8\end{array}$ & $\begin{array}{l}+3 \cdot 7^{*} \\
\pm 1 \cdot 5\end{array}$ & $\begin{array}{l}+3 \cdot 3^{*} \\
\pm 1 \cdot 6\end{array}$ \\
\hline
\end{tabular}

Statistically significant differences are shown by asterisks; thus the range $0.05>\boldsymbol{P}>0.02$ is indicated by ${ }^{*}$ and the range $0.02>P$ by ${ }^{* *}$.

TABLE IV

EMPIRICAL COEFFICIENTS OBTAINED WHEN EQUATION (4) IS FITTED TO SODIUM EFFLUX RATES IN CONTROL ANIMALS AND IN THE TWO EXPERIMENTAL GROUPS

The curve represented by Equation (4) was fitted according to the methods described by Lipka (1918)

\begin{tabular}{|c|c|c|c|c|c|c|c|c|c|}
\hline Group & .. & .. & . & .. & A & $\propto$ & B & $\beta$ & C \\
\hline Controls & .. & . & .. & . & +1.48 & $-0 \cdot 107$ & +0.87 & -0.023 & +0.60 \\
\hline \multicolumn{3}{|c|}{ Inhibitors (all animals) } & . & .. & +1.68 & -0.091 & $+1 \cdot 15$ & -0.033 & +0.24 \\
\hline DNP only & .. & . & $\ldots$ & $\ldots$ & $+3 \cdot 35$ & -0.17 & +0.69 & -0.028 & +0.27 \\
\hline
\end{tabular}




\section{Discussion}

From Tables I and II and Figs 4 to 8, it would appear that both the rates of solute efflux and the concentrations of effluent decreased rapidly during the first 20 to 40 minutes of the experiment, and became relatively steady during the period 60 to 120 minutes. During this latter phase the variance between animals was considerably less than during the first 40 minutes, and it is reasonable to regard this phase as a steady state or an approximation thereto. For the reasons discussed below, the efflux rates during the last 40 minutes of the experiment were taken as measuring the influx rates of solutes into the aqueous compartment of the eye, so that the rates of entry in the control series were $0.632 \mu \mathrm{Eq} . / \mathrm{min}$. for sodium, $30.8 \mu \mu \mathrm{Eq} . / \mathrm{min}$. for potassium, and $9.86 \mu \mu \mathrm{M} / \mathrm{min}$. for calcium.

Corresponding values for the group treated with DNP were $0 \cdot 271 \mu \mathrm{Eq} . / \mathrm{min}$. for sodium, $30 \cdot 2 \mu \mu \mathrm{Eq}$. $/ \mathrm{min}$. for potassium, and $6.79 \mu \mu \mathrm{M} / \mathrm{min}$. for calcium.

The mean value for sodium obtained by pooling results from all experiments in which an inhibitor had been given was $0.304 \mu$ Eq./min. Potassium and calcium were estimated only in animals given DNP.

Sodium.-A steady state for the transfusate is attained when $\frac{d}{d t} \cdot c_{e} \rightarrow 0$, and under this condition Equation 4 becomes:

$$
\frac{d}{d t} \cdot m_{a e}=\mathrm{C}=\frac{d}{d t} \cdot m_{p a},
$$

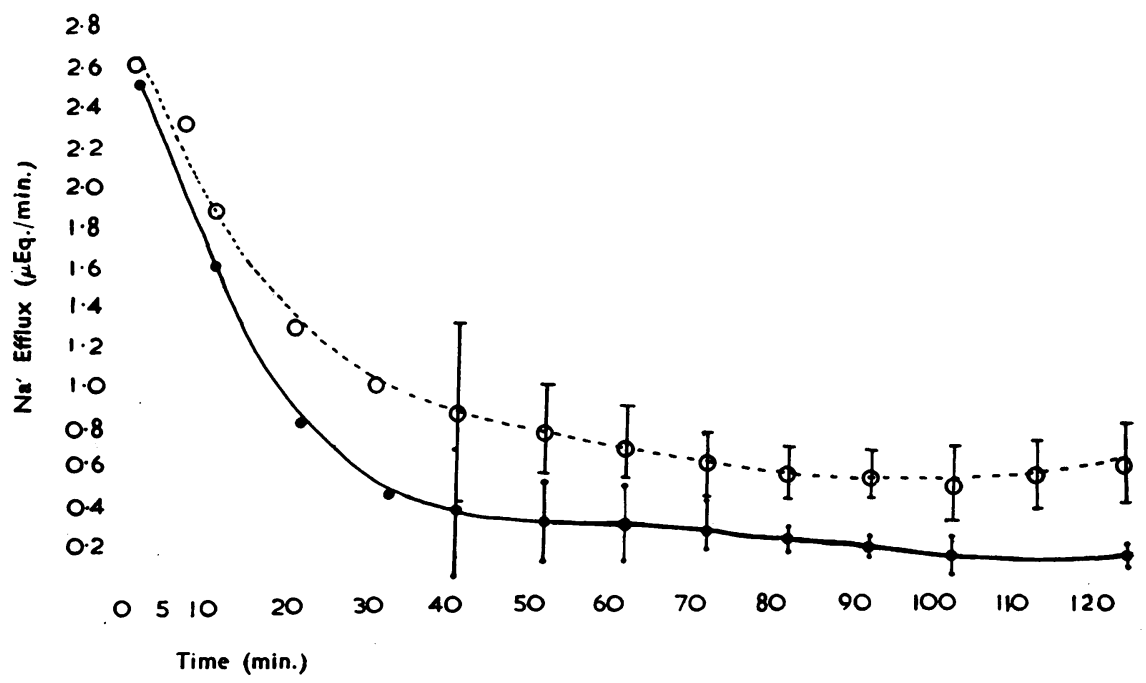

FIG. 4.-Change in sodium efflux with time in control eyes and in all eyes in which inhibitors were given.

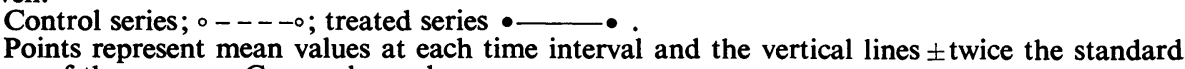
error of the means. Curves drawn by eye. 

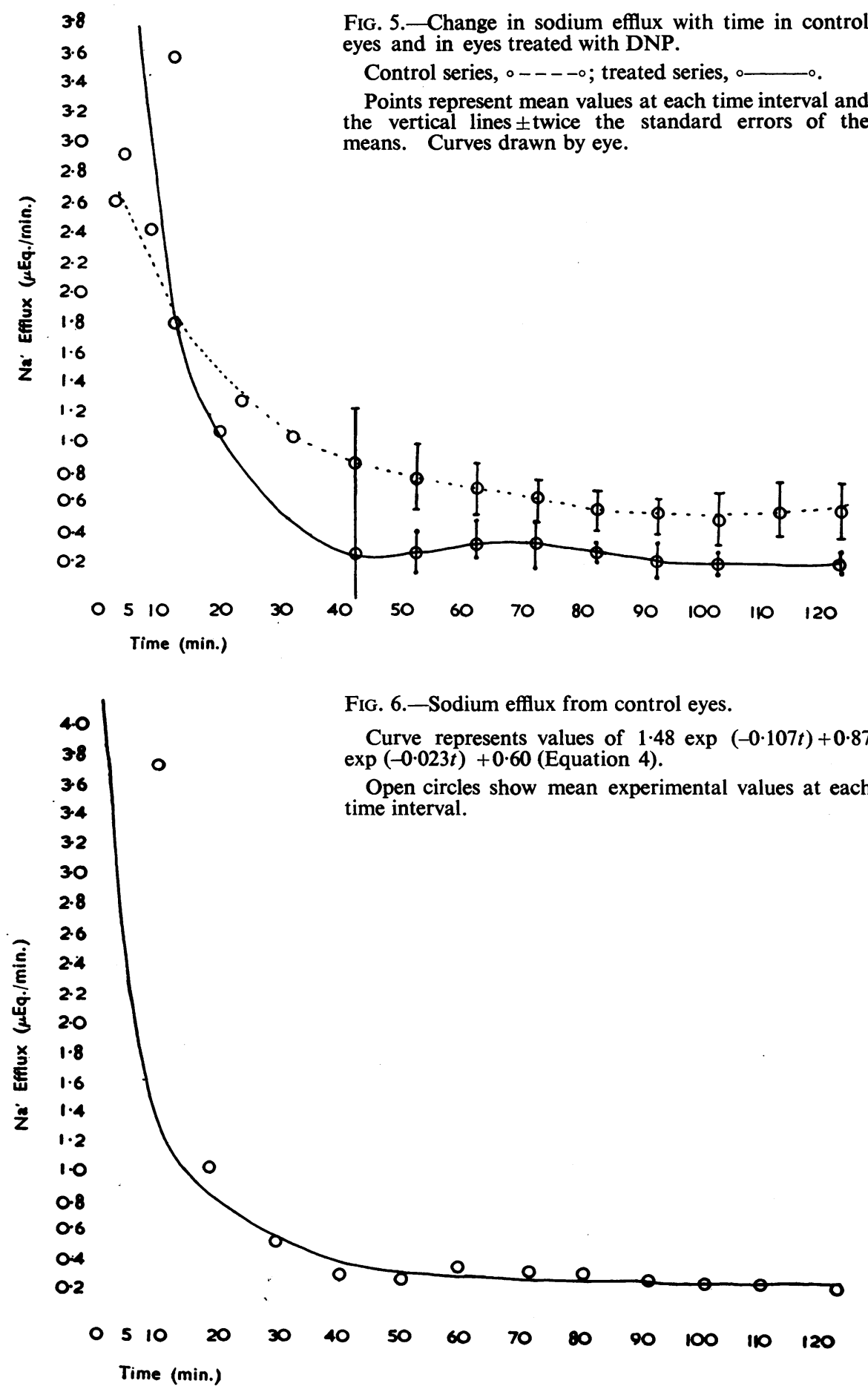

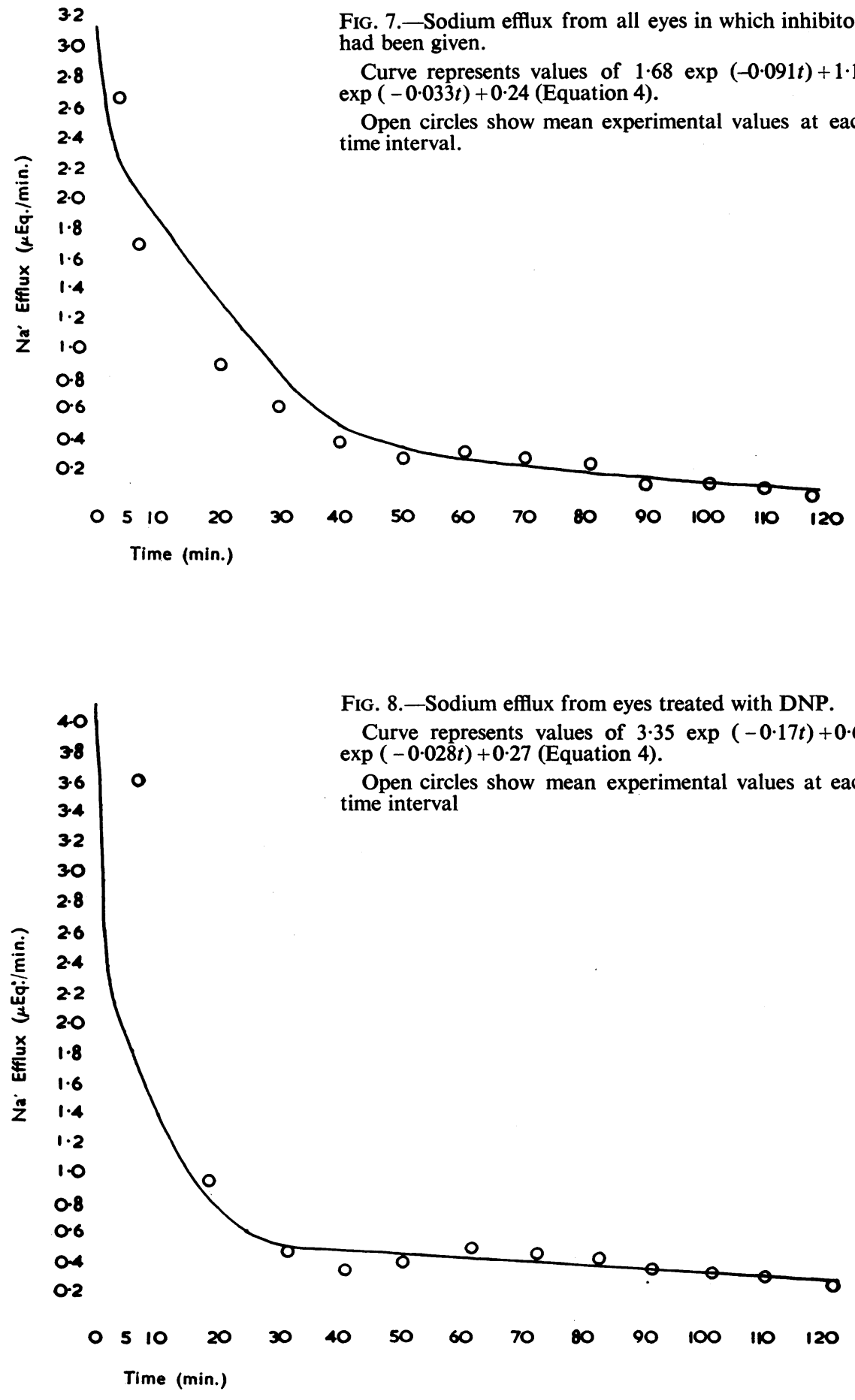
and hence $\mathrm{C}$ is a measure of the steady state efflux rate and thus of the rate of entry. Empirical constants for Equation 4 as applied to sodium efflux are given in Table IV and the values for $\mathrm{C}$ are $0.600 \mu \mathrm{Eq} . / \mathrm{min}$. (control series), $0.240 \mu \mathrm{Eq} . / \mathrm{min}$. (all treatments), and $0.270 \mu \mathrm{Eq} . / \mathrm{min}$. (DNP only). These results are in fair agreement with the estimates from the mean efflux rate during the last 40 minutes of the experiments (Figs 6 to 8).

The processes comprised in the steady state rate of entry may be considered as falling into one of three kinds: direct or indirect diffusion from plasma to the tranfusing fluid (transfusate), ultrafiltration through a barrier the permeability of which to large molecules can vary considerably, and secretion across the blood-aqueous barrier dependent upon the metabolic activity of certain regions in the ciliary epithelium. All processes may contribute simultaneously to the total rate of entry, and it was anticipated that toxic materials capable of inhibiting sodium transport (either directly or indirectly) would reduce the total rate of entry by inhibiting the secretory component. Hence, if the transfusion method described above is capable of estimating the rate at which sodium or some other solute enters the eye across the bloodaqueous barrier, then a substance which inhibits active transport across the ciliary epithelium will reduce the rate of entrance and the steady state efflux, as estimated by this technique. The inhibitor used in the majority of the experiments was DNP, which is known to inhibit active transport in a number of tissues (Fuhrman, 1952; Schoffeniels, 1955; Hoshiko, Swanson, and Visscher, 1956) and has been shown to affect the formation of aqueous in the posterior chamber (Cole, 1959). In a few experiments Diamox was used as an inhibitor, and in others the mercurial diuretic, Mersalyl.

Although inhibition of active transport will reduce the steady state efflux, it is necessary to consider whether (and in what circumstances) the converse is true. If a reduction of steady state efflux is not due to inhibition of secretion, it must be explained either by a decrease in the rate at which the solute enters by diffusion and ultrafiltration across the blood-aqueous barrier, or else by a steady loss of solute from the aqueous so that not all the solute entering the eye reaches the collecting system. For two reasons it is improbable that in the present experiments the passive entrance of solutes was significantly reduced after giving DNP:

(a) Effluent was collected from treated animals and its appearance after adding 5 per cent. trichloracetic acid was compared with that collected from untreated animals. The effluent from control animals contained, with very few exceptions, only traces of protein and the amount did not appear to increase during the 2 hours of the experiment; on the other hand, when DNP had been given, the protein content of the effluent was greater and sometimes increased slightly during the experiment. This indicates that DNP had increased the permeability of the blood-aqueous barrier so that protein from the plasma was able to enter the eye more rapidly. If DNP had made the barrier more permeable to large molecules such as plasma proteins, it is unlikely that it would have impeded at the same time 
the penetration of the much smaller sodium ion. It is more probable that DNP increased the passive entrance of water and solutes from the plasma, resembling the action of D.F.P., which increases both the intra-ocular pressure and the protein concentration of the aqueous (von Sallmann and Dillon, 1947). Furthermore, the facts that the steady state efflux of potassium was not reduced by DNP, that the calcium efflux, while reduced, remained higher than anticipated, and that the increased protein concentration persisted, argue against the presence of an appreciable vascular stasis (cf. Poos, 1931; Larsson, 1932) which would diminish the transfer of all constituents from blood into the aqueous. Furthermore, there was a very considerable fall in concentration from plasma to transfusate, which would have favoured a relatively high rate of entry by diffusion in both the control and experimental animals.

(b) In the second place, it is also improbable that there could have been any loss of sodium from the transfusate between the sites of entry and the collecting system. The tissues with which the transfusate came into contact (vitreous, lens, cornea) had been, immediately before the transfusion commenced, in equilibrium with normal aqueous containing approximately $150 \mu \mathrm{Eq}$. sodium per $\mathrm{ml}$. With the commencement of transfusion, the sodium concentration of fluid in the eye decreased and the effluent concentration reached a steady state value of 12.48 $\mu \mathrm{Eq}$. $/ \mathrm{ml}$. in control animals and $4.95 \mu \mathrm{Eq} . / \mathrm{ml}$. in experimental animals; there was a net movement of sodium into the transfusate from the surrounding tissues until a new steady state was attained.

Thus it follows that, in addition to the washing out of the aqueous humour initially contained in the eye which occurs rapidly with a rate constant approaching $F_{o} / V_{a}$ and represented by $\propto$ in Equation 4), there is a slower process (represented by $\beta$ in Equation 4) which is due to sodium loss and equilibration of the tissues bounding the aqueous.

Vitreous.-On the basis of values reported by Maurice (1957), the area of the blood-vitreous boundary was $6.1 \mathrm{~cm} .{ }^{2}$ and a transfer constant $\left(K_{v p}\right)$ $0.00018 \mathrm{~cm}$. min. ${ }^{-1}$, while the vitreous-aqueous surface had an area of 1.0 $\mathrm{cm}^{2}$ and $K_{v a}$ of $0.0017 \mathrm{~cm}$. min. ${ }^{-1}$. The sodium concentration in the transfusate in the posterior chamber was taken as not greater than 12.0 $\mu \mathrm{Eq} . / \mathrm{ml}$. Regarding the vitreous as a single compartment, a steady state exists when:

$$
\frac{d}{d t} \cdot m_{v}=\frac{d}{d t} \cdot m_{p v}-\frac{d}{d t} \cdot m_{v a}=0=K_{p v} A_{p v}\left(c_{p}-c_{v}\right)-K_{v a} A_{v h}\left(c_{v}-c_{h}\right),
$$

which gives, on substitution of known or estimated parameters:

$$
\frac{d}{d t} \cdot m_{v a} \leqq 0.087 \mu \mathrm{Eq} . / \mathrm{min} \text {. }
$$

This steady state is not reached for at least $5 \mathrm{hrs}$ (Maurice 1957), and sodium loss from the anterior region occurs faster, and from the posterior 
regions more slowly, than an exponential decrease from a single compartment would suggest. An estimate of the rates may be obtained by considering the total loss due to a series of different sodium concentrations each present in the vitreous for different periods of time.

Using the equation given by Maurice (1957), it appeared that after the first 2 minutes about $17 \mu \mathrm{Eq}$. and after the first 14 minutes about $50 \mu \mathrm{Eq}$. sodium had moved into the transfusate from the vitreous. After 20 to 30 minutes the rate was very much slower and, towards the end of the 2 hours, the collection was less than $0 \cdot 1 \mu \mathrm{Eq}$./min., little more than the steady state entrance.

Lens.-The sodium concentration of lens is greatest in the capsule and decreases from cortex to medulla. The capsular and cortical sodium migrate rapidly into a sodium-free solution (Amoore, Bartley, and van Heyningen, 1959), and the concentration throughout the whole organ drops to between 10 and $15 \mu \mathrm{Eq} . / \mathrm{ml}$. In the present experiments, this initial sodium loss may be regarded as contributing to the sodium in the first 20 to 30 minutes, but because the lens is isolated from the blood circulation sodium cannot transfer through it from plasma to aqueous.

Cornea.-The steady state entrance of sodium from the cornea was estimated in the same way as that from the vitreous, using the transfer constants determined by Maurice (1951). At a first approximation it appeared that $\frac{d}{d t} \cdot m_{c a}$ decreased exponentially with a rate constant of 0.026 min. ${ }^{-1}$, to attain a steady state with $\frac{d}{d t} \cdot m_{c a} \leqq 0 \cdot 1 \mu \mathrm{Eq} . / \mathrm{min}$.

The steady state rates of sodium entrance would contribute to the total rate of entrance by diffusion and would not be distinguished from diffusion across the blood-aqueous barrier. These rates of entry are estimated maximal values, calculated on the assumption that migration of sodium into the transfusate was accompanied by isosmotic movement of water. Were this not entirely true and were there also some exchange of sodium for mannitol, the sodium entrance rates would be limited by the permeability of the tissues to mannitol, and would be less than the estimated values.

It may be concluded that, neither in the control not the experimental series, would the sodium loss from tissues bounding the aqueous account for the efflux from the eye during the last 40 minutes of the experiment.

Potassium.-The mean concentration of potassium in plasma water was $4.97 \pm 0 \cdot 17 \mu \mathrm{Eq} . / \mathrm{ml}$. (all animals); had its rate of entrance into the eye been in the same ratio to sodium influx as is the concentration ratio, $\mathrm{K}: \mathrm{Na}$ in 
plasma, a net influx of $0.021 \mu \mathrm{Eq} . / \mathrm{min}$. would be expected at the steady state. The actual rate in the control animals, $0.0308 \mu \mathrm{Eq} . / \mathrm{min}$., exceeded this estimate, and it is probable that the additional $0.010 \mu \mathrm{Eq}$. $/ \mathrm{min}$. came from the lens. Potassium concentration in the lens is $110-120 \mu \mathrm{Eq} . / \mathrm{ml}$. (Amoore and others, 1959), and rabbit lenses would contain some $75 \mu$ Eq. potassium, of which 20-30 $\mu$ Eq. could be lost to the environment when the metabolism of the organ was disturbed (Harris and Gehrsitz, 1951). In addition, the isotope ${ }^{42} \mathrm{~K}$ is known to equilibrate between plasma and lens in about 2 hours (Davson, 1955), and a larger contribution might have been expected to potassium efflux from the eye. After administering DNP, the entry rate of potassium, calculated as before was $0.009 \mu \mathrm{Eq}$. $/ \mathrm{min}$., whilst the efflux had remained unchanged, indicating that more potassium $(0.020 \mu \mathrm{Eq} . / \mathrm{min}$.) had entered the transfusate during its passage through the eye. This may well have been due to disturbance of lens metabolism by DNP increasing the loss of potassium. It needs to be recalled that, both in these experiments and in the controls, the sodium efflux from transfusate to lens would be limited by the low sodium concentration of the transfusate. If the sodium uptake and potassium loss is an exchange process of $\mathrm{Na}^{\cdot}$ for $\mathrm{K} \cdot$ (Harris and Gehrsitz, 1951), this limitation of sodium entry would also have limited potassium loss and would explain why a greater difference was not observed between calculated entry rate and total efflux of potassium.

Calcium. - The mean total concentration in plasma (all animals) was 1.5 $\mu \mathrm{M} / \mathrm{ml}$., and the rate of calcium entry calculated to yield a $\mathrm{Ca}: \mathrm{Na}$ ratio similar to that of normal aqueous humour ranged between 4 and $6 \mu \mu \mathrm{M} / \mathrm{min}$. Both in the control- and DNP-treated animals the calcium effluxes were 2 to $4 \mu \mu \mathrm{M} / \mathrm{min}$. greater than had been expected, and while this may have been partly due to calcium already in the eye equilibrating more slowly with the transfusate than did sodium, it also suggests, that, relative to sodium, the blood-aqueous barrier permeability to calcium had increased. After treatment with DNP, the calcium efflux did not decrease in proportion to the fall of sodium efflux, indicating that there was not a simple relationship of dependence between calcium entrance and that component of sodium transport into the eye which is subject to inhibition by DNP. If the experiments in which the control and experimental values were obtained from opposite eyes of the same animal are considered, the effects of DNP on calcium efflux are of doubtful significance.

Evaluation of Values for Sodium Influx.-At first sight the values for the component of sodium influx which was subject to inhibition by DNP or Diamox appear to be about one half of the amount entering an intact eye by secretion as calculated from figures already available in the literature. Langham (1958), for example, gives the net rate of sodium influx as approximately $0.75 \mu \mathrm{Eq} . / \mathrm{min}$. Before accepting this conclusion, however, it is 
worth considering in more detail the derivation of a value for net rate of influx from results obtained with ${ }^{24} \mathrm{Na}$. By using the value, $k_{f}=0.017$ min..$^{-1}$ from the first evaluation of their experimental findings by Kinsey and Palm (1955) and the theoretical considerations of Friedenwald and Becker (1956), and by accepting $V_{a}=0.29 \mathrm{ml}$. (Copeland and Kinsey, 1950; Maurice, 1957), a value of $4.93 \mu \mathrm{l} . / \mathrm{min}$. is obtained for rate of flow from posterior to anterior chamber and from anterior chamber to drainage channels, $\left(F_{o}\right)$.

This is approximately equal to the figure of $5 \mu 1 . / \mathrm{min}$. which has been indicated previously by Maurice (1957) and Langham (1958). Earlier work by Kinsey and Grant (1942) had shown a mean value of $143 \mu \mathrm{Eq} . / \mathrm{ml}$. for sodium concentration in the anterior chamber aqueous, and a value for steady state efflux, which is equal to influx, may be obtained by substituting in:

$$
\begin{aligned}
\frac{d}{d t} \cdot m_{o} & =c_{a} \cdot F_{o}=\frac{d}{d t} \cdot m_{h a} \\
& =0.705 \mu \mathrm{Eq} . / \mathrm{min} .
\end{aligned}
$$

However, there are reasons for supposing that $0.017 \mathrm{~min}^{-1}$ is too high a value for $k_{f}$. In the first place Kinsey and Palm (1958) have revised their evaluation of the experimental findings published earlier (Kinsey and Palm, 1955) and now give $0.0100<k_{f}<0.0125 \mathrm{~min}^{-1}$. In the second place, other methods of estimating the rate of flow of the aqueous imply that $k_{f}$ lies between 0.0107 and 0.0130 min. $^{-1}$ (Bárány and Kinsey, 1949; Kinsey and Bárány, 1949). Should these latter values be that more nearly correct, the estimate of $\frac{d}{d t} \cdot m_{o}$ given above should be reduced by between 30 and 40 per cent. Another possibility is that the animals used in the present experiments had an average of less than $0.29 \mathrm{ml}$. aqueous humour per eye. Measurements of $V_{a}$ made 9 years ago on rabbits at this Institute by Maurice (1951) yielded an average value of $0 \cdot 253 \pm 0.015 \mathrm{ml}$. and (although it is conceded that this may be an underestimate), using this figure for $V_{a}$ and taking $k_{f}=0.01125 \mathrm{~min} . .^{-1}$ and $c_{a}$ as $143 \mu \mathrm{Eq} . / \mathrm{ml}$., the following figures are obtained:

$$
\begin{aligned}
F_{o} & =2.85 \mu \mathrm{l} . / \mathrm{min} . \\
\frac{d}{d t} \cdot m_{o} & =0.407 \mu \mathrm{Eq} . / \mathrm{min} .
\end{aligned}
$$

This value, which should represent the amount of sodium per minute entering the intact eye by secretion, is very little greater than the component of influx which was inhibited by DNP in the experiments described in this paper. Furthermore, it is most improbable that the rate of operation of the metabolic process which was responsible for secretion would have been independent of temperature; the rapid transfusion entailed in these experiments would have tended to cool the ocular tissues and thus to decrease the rate of active transport. 
It is obvious that in intact eyes the net influx of sodium due to diffusion must be very much less than the net diffusion influx estimated in these transfusion experiments, because the concentration difference $\left(c_{p}-c_{a}\right)$ is very small in comparison with that in the transfused eye. The value of 0.0125 min. $^{-1}$ reported for $k_{d}\left(=k_{a . p a}\right)$ by Kinsey and Palm (1958) shows that the blood-aqueous barrier in intact eyes is sufficiently permeable to ${ }^{24} \mathrm{Na}$ for the actual flux in either direction to be as great as, or greater than the $0.27 \mu \mathrm{Eq}$./min. observed in the animals given metabolic inhibitors.

Taken together, these considerations are consistent with the view that the technique which has been described affords an estimate of the rate at which sodium was crossing the blood-aqueous barrier into the eye, and also that there was a component of sodium influx which was dependent upon normal tissue metabolism and which represented the secretory component of aqueous humour formation in the normal eye.

In explanation of observations already reported (Cole, 1959), it was suggested that a fall in intra-ocular pressure observed after systemic administration of hypotonic solutions and an intra-lingual injection of DNP was caused by inhibition of the mechanism of secretion of a solute, such as sodium ion, into the aqueous. It was proposed, as an explanatory hypothesis, that the entry of water and solutes into the aqueous approximated to isosmotic transfer, so that:

$$
\frac{\left(\frac{d}{d t} \cdot m_{p a}\right)}{\left(\frac{d}{d t} \cdot v_{p a}\right)}=C_{p} .
$$

Knowing from the concentrations of the chief plasma cations that $6.55 \mu 1$. water was associated with each $\mu \mathrm{M}$ cation, the present results show that the change in cation influx caused by DNP administration could account for a reduction in the water influx by almost $2.5 \mu \mathrm{l} . / \mathrm{min}$. in an intact eye, which would certainly be adequate to explain any fall in intra-ocular pressure. In transfusion experiments such as those discussed above, an alteration in water efflux of this magnitude would not be detected; the transfusion rate was maintained at $50 \mu 1 . / \mathrm{min}$. and the concentration of sodium in the transfusate was decreased by DNP. However, preliminary experiments indicate that DNP causes a considerable reduction in the rate of aqueous formation in non-transfused eyes with the outflow channels blocked.

\section{Summary}

It is already known that the continuous formation and flow of the aqueous humour is largely due to the ciliary epithelium transporting water and solutes from plasma into the posterior chamber. The rate of formation of aqueous is related, amongst other factors, to the rate of entry of solutes, 
the chief constituent of which in both plasma and aqueous is the sodium ion. Previous observations of the effects of certain metabolic inhibitors upon the intra-ocular pressure had indicated a reduction in sodium influx from plasma to aqueous and, as a consequence, a decrease in the rate of formation of aqueous.

The rates at which sodium and water enter the aqueous have hitherto been measured indirectly by the transfer coefficients of sodium and by the aqueous flow constant. In the present experiments the sodium influx has been measured directly as a quantity per unit of time, in order to establish whether it was decreased by a metabolic inhibitor which was already known to modify the intra-ocular pressure.

For this purpose a method was devised for transfusing the aqueous compartment of the rabbit eye with sodium-free, isotonic, mannitol solution, buffered at $\mathrm{pH} 7 \cdot 45$, the intra-ocular pressure not being allowed to fall below $30 \mathrm{~mm}$. Hg. The normal drainage channels were occluded with mineral oil so that all the effluent fluid could be collected, and measured, and the concentrations of sodium, potassium, and calcium determined. The efflux rates of these ions were then calculated for successive 10-minute intervals for 2 hours after the commencement of the transfusion.

During the first 30 minutes the aqueous humour originally present in the eye was being washed out and the efflux rates decreased rapidly, only approaching stable values after 80 minutes. Experiments were performed comparing untreated eyes (as controls) with eyes which had been exposed to 2, 4 : dinitrophenol (DNP), which is known to inhibit certain secretory activities especially those concerned in sodium transport, or, in a few cases, to "Diamox" or "Mersalyl".

In the case of sodium, the stable efflux rate was regarded as a measure of the rate at which the ion entered the aqueous from plasma; this averaged $0.632 \mu \mathrm{Eq} . / \mathrm{min}$. in the control series and $0.271 \mu \mathrm{Eq} . / \mathrm{min}$. in eyes treated with dinitrophenol. The potassium efflux rate in untreated animals was 30.8 $\mu \mu \mathrm{Eq} . / \mathrm{min}$. and this remained unaltered $(30 \cdot 2 \mu \mu \mathrm{Eq} . / \mathrm{min}$.) when dinitrophenol was given. However, owing to the high potassium content of the lens, these figures could not be regarded as necessarily implying that the rate at which potassium entered the posterior chamber was unaffected by the inhibitor. The calcium efflux rate in the control and treated groups was 9.86 $\mu \mu \mathrm{M} / \mathrm{min}$. and $6.79 \mu \mu \mathrm{M} / \mathrm{min}$. respectively. In both groups the ratio of calcium efflux to sodium efflux was greater than had been expected from the values in aqueous from intact eyes. The ratio was greater in eyes treated with dinitrophenol than in control eyes, suggesting that the inhibitor had increased the permeability of the blood-aqueous barrier to calcium although the rate of sodium entry had diminished.

That component of the total sodium influx which was subject to inhibition by dinitrophenol amounted to approximately $0.390 \mu \mathrm{Eq}$. $/ \mathrm{min}$., and arguments are presented which indicate that this component was a measure of the rate 
of sodium secretion from blood to aqueous in the intact eye. On the hypothesis that the secretion was approximately isomotic with plasma, active transfer of sodium at $0.390 \mu \mathrm{Eq}$./min. would have accounted for an aqueous flow of about $2.5 \mu 1$./min., in reasonable agreement with calculations based upon total volume of aqueous and published values for the flow constant of aqueous derived from the entry rate of radioactive sodium.

The author wishes to express his thanks to Sir Stewart Duke-Elder for his advice and encouragement and for the facilities afforded to make this investigation possible.

\section{REFERENCES}

Amoore, J. E., Bartlęy, W., and Van Heyningen, R. (1959). Biochem. J., 72, 126.

BÁRÁNY, E., and KINSEY, V. E. (1949). Amer. J. Ophthal., 32, No. 6, pt. 2, 177.

COLE, D. F. (1959). Brit. J. Ophthal., 43, 268.

CoPeland, R. L., and Kinsey, V. E. (1950). Arch. Ophthal. (Chicago), 44, 515.

Davson, H. (1955). J. Physiol. (Lond.), 129, 111.

(1956). "Physiology of the Ocular and Cerebrospinal Fluids", pp. 133-134. Churchill, London.

Duke-Elder, S., and Maurice, D. M. (1957). Brit. J. Ophthal., 41, 792.

FRIEDENWALD, J. S., and BECKER, B. (1956). Amer. J. Ophthal., 41, 383.

Fuhrman, F. A. (1952). Amer. J. Physiol., 171, 266.

GoldMANN, H. (1950). Ophthalmologica (Basel), 119, 65.

HarRIS, J. E., and Gehrsitz, L. B. (1951). Amer. J. Ophthal., 34, No. 5, pt. 2, 131.

Hoshiko, T., Swanson, R. E., and Visscher, M. B. (1956). Amer. J. Physiol., 184, 542.

KINSEY, V. E., and BÁRÁNY, E. (1949). Amer.J. Ophthal., 32, No. 6, pt. 2, 189. and GRANT, W. M. (1942). J. gen. Physiol., 26, 131.

KinSEY, V., and PALM, E. (1955). A.M.A. Arch. Ophthal., 53, 330. and - (1958). Brit. J. Ophthal. 42, 620.

LANGHAM, M. E. (1958). Physiol. Rev., 38, 215.

(1959). J. Physiol. (Lond.), 147, 29P.

and Wood, P. (1956). Ibid., 132, 55P.

Larsson, S. (1932). Ann. Oculist., Paris, 169, 94.

LIPKA, J. (1918). "Graphical and Mechanical Computation". Wiley, New York.

MAURICE, D. M. (1951). J. Physiol. (Lond.), 112, 367. (1957). Ibid., 137, 110.

Phillips, R. A., van Slyke, D. D., Dole, V. P., Emerson, K., Hamilton, P. B., and Archibald, R. M. (1945). "Copper Sulfate Method for Measuring Specific Gravities of Whole Blood and Plasma". (From the United States Navy Research Unit at the Hospital of the Rockefeller Institute for Medical Research). New York.

Poos, F. (1931). v. Graefes Arch. Ophthal., 127, 489.

von SallmanN, L., and Dillon, B. (1947). Amer. J. Ophthal., 30, 1244.

SCHOFfENIELS, E. (1955). Arch. intern. Physiol., 63, 361.

Sunderman, F. W., and BoERnER, F. (1949). "Normal Values in Clinical Medicine," p. 94. Saunders, Philadelphia,

Winterstein, H. (1935). Pflug. Arch. ges. Physiol., 235, 377. 